\title{
ANALISIS HARGA SUATU BARANG DI LINGKUNGAN MASYARAKAT
}

\author{
Nezella Ningrum Diah Fatmala \\ IAIN PONOROGO \\ e-mail: nezellandf@gmail.com
}

\begin{abstract}
In the world of trading, price is an important part of a trader. because, price is a measuring tool that can be used as a benchmark for the value of an item. with the distribution pattern of goods in an area, the price level greatly affects the demand and supply of goods at the consumer level. There are several factors that can affect the price-fixing process, namely the price of raw materials, the cost of producing goods, the cost of marketing the product, regulations made by the government, the price of similar products sold by competitors, and discounts for distributors and consumers. in other words, the price is the amount of exchange rate that can be equated with money or other goods of equal value and can be used to obtain a product or service needed by a consumer. as for the purpose of the price agreement is to meet human needs in achieving prosperity and welfare.
\end{abstract}

Keywords: Price, Market, Goods

\begin{abstract}
Abstrak
Dalam dunia perdagangan harga merupakan suatu bagian terpenting bagi seorang pedagang. karena, harga merupakan alat ukur yang dapat dijadikan sebagai patokan nilai suatu barang. dengan adanya pola distribusi barang disuatu daerah maka tingkat harga sangat mempengaruhi permintaan dan penawaran barang ditingkat konsumen. terdapat beberapa faktor yang dapat mempengaruhi proses penetapan suatu harga yaitu harga dari bahan baku, biaya produksi barang, biaya pemasaran produk, peraturan yang dibuat oleh pemerintah, harga produk yang sejenis dijual oleh pesaing, dan diskon bagi distributor dan konsumen. dengan kata lain harga adalah jumlah nilai tukar yang dapat disamakan dengan uang atau barang lain yang senilai dan dapat digunakan untuk mendapatkan suatu produk maupun layanan yang dibutuhkan oleh seorang konsumen. adapun tujuan dari kesepakatan harga adalah untuk memenuhi kebutuhan manusia dalam mencapai kemakmuran dan kesejahteraan.
\end{abstract}

\section{Kata Kunci : Harga, Pasar, Barang}

\section{PENDAHULUAN}

Permasalahan yang sering muncul dalam kegiatan berbisnis adalah bagaimana menentukan harga jual yang tepat bagi para pembeli (konsumen), seorang pebisnis perlu mempertimbangkan biaya yang telah digunakan dalam proses produksi dan mengetahui 
perubahan apa saja yang terjadi dalam kuantitas produksi apabila ingin menetapkan harga jual secara efektif. Dengan demikian harga digunakan sebagai indikator suatu nilai bilamana indikator tersebut berhubungan atas kemanfaatan yang dirasakan oleh para pembeli terhadap suatu barang atau jasa tersebut. Jadi kesimpulannya jika konsumen merasakan manfaat atas barang atau jasa tersebut lebih banyak, maka harganya akan semakin meningkat.

Suatu harga digunakan sebagai faktor penentu pembeli dalam menentukan keputusan transaksi pembelian atas barang maupun jasa. Apabila barang atau jasa tersebut merupakan kebutuhan sehari-hari yang wajib dibeli misalnya seperti makanan, minuman, kebutuhan pokok, dan kebutuhan pelengkap lainnya, maka konsumen tersebut akan memperhatikan tingkat harganya. Para pelaku bisnis sebaiknya memperhatikan hal-hal yang berkaitan tentang harga karena dalam persaingan usaha, harga yang ditawarkan oleh pesaing bisa lebih rendah dengan kualitas yang tidak kalah bagus. Sehingga dalam menentukan harga produk atau jasa yang ingin dijual sebaiknya perusahaan besar maupun usaha kecil harus memperhatikan para konsumen dan pesaingnya. Dalam hal pembelian, konsumen sangat memperhatikan harga dan kemudian konsumen tersebut menyesuaikan dengan kemampuan yang dimilikinya. Tingkatan harga diklasifikasikan menjadi tiga tahapan yaitu murah, sedang, dan mahal.

Perusahaan merupakan suatu bentuk organisasi usaha dimana terdapat sumber daya seperti bahan baku dan tenaga kerja yang dimanfaatkan untuk diproses agar menghasilkan suatu produk atau barang yang nantinya akan dijual kepada pelanggan. Adapun tujuan dari perusahaan ialah untuk mencari laba atau keuntungan. Laba adalah selisih dari harga penjualan (uang yang diterima penjual dari seorang pembeli karena terjadi transaksi jual beli suatu barang), dengan biaya produksi (biaya yang dikeluarkan untuk proses pembuatan produk yang akan dijual oleh perusahaan).

Dalam menentukan harga jual yang tepat, perusahaan harus mengetahui harga pokok produksi terlebih dahulu, karena harga pokok produksi merupakan komponen dasar dalam menentukan harga jual barang. Harga pokok produksi adalah beban atau biaya yang secara langsung maupun tidak langsung dikeluarkan oleh perusahaan yang digunakan dalam proses produksi. Bagi suatu perusahaan penetapan harga pokok produksi merupakan peranan yang sangat penting sebab dari harga pokok produksi dapat dibuat analisa suatu rencana dan bisa mengetahui kekuatan pemasaran produk serta menentukan harga jual dan laba perusahaan.

Di dalam teori ekonomi Mikro dijelaskan bahwa kegiatan berbisnis merupakan kegiatan yang berguna sebagai penggerak sosial ekonomi secara keseluruhan. Semakin banyak orang yang terjun dalam kegiatan bisnis disuatu daerah maka semakin terbuka peluang daerah tersebut dan akan mengalami kemajuan disegala aspek kehidupan. Kegiatan bisnis membuka peluang sebagai tempat penyedia lapangan pekerjaan bagi masyarakat yang membutuhkan serta mampu menumbuhkan ide kreatif dan inovatif bagi masyarakat. Selain itu bisnis juga menghasilkan barang atau jasa yang berguna untuk memenuhi kebutuhan manusia, karena kebutuhan manusia sifatnya tidak terbatas dan berlangsung secara terus menerus sedangkan faktor ekonomi hanya menghasilkan barang atau jasa yang sifatnya 
terbatas. Dengan demikian para pelaku bisnis termotivasi sehingga ikut andil dalam beroperasi guna untuk memenuhi kebutuhan hidup yang semakin kompleks. Dan sebelum melaksanakan kegiatan bisnis diperusahaan alangkah baiknya para pelaku bisnis mengenal terlebih dahulu tentang studi kelayakan bisnis agar dapat mengetahui dan menganilisis kelayakan bisnis yang akan dijalankan. Tujuan dari kegiatan tersebut adalah untuk meminimalkan resiko kegagalan dan kerugian, selain itu dalam bisnis terdapat investasi (kegiatan menanamkan modal kepada sejumlah bisnis guna mendapatkan profit atau keuntungan). Didalam kegiatan investasi, jenis usaha sangat ditentukan oleh jenis produk atau jasa yang dibutuhkan dalam rangka memenuhi kebutuhan masyarakat.

Jika investasi yang diusulkan itu mampu atau layak secara ekonomis, maka lembaga pembiayaan (Bank) bersedia untuk memberikan kredit sebagai modal usaha dan modal investasi yang sesuai dengan kebutuhan, dan pengguna modal harus bisa memanfaatkan modal tersebut secara efisien agar mampu menghasilkan laba yang optimal. Tujuan lain yang ingin dicapai perusahaan yaitu dapat menghasilkan dan menyediakan produk atau jasa yang berguna untuk kepentingan masyarakat umum supaya mampu memberikan manfatat dan kemakmuran bagi masyarakat.

\section{METODE PENELITIAN}

Penelitian ini dilakukan di Dsn. Krajan, Ds. Sukorejo, Kec. Sukorejo, Kab. Ponorogo, Provinsi Jawa Timur pada hari Selasa, 02 Juni 2020. Dalam menyusun laporan ini, menggunakan metode analisis kuantitatif yaitu metode yang menjelaskan hubungan antara variabel dengan teori dan malakukan generalisasi terhadap fenomena sosial yang diteliti, subjek pada penelitian kuantitatif disebut dengan responden. Untuk memperoleh data dan informasi yang diperlukan dalam penelitian dilakukan dengan cara mengumpulkan data dari serangkaian instrumen penelitian yang berupa tes atau kuisioner. Untuk data yang sudah terkumpul selanjutnya dikonversikan dengan menggunakan kriteria atau kategori yang sudah ditetapkan sebelumnya. Dengan menyajikan data yang yang diproyeksikan kedalam bentuk tabel kemudian akan dibahas dan didiskripsikan dengan cara mengkolerasikan data yang diperoleh dengan teori.

\section{HASIL DAN PEMBAHASAN Harga}

Harga adalah sejumlah uang yang ditambah dengan beberapa produk yang memungkinkan dan digunakan untuk mendapatkan sejumlah kombinasi produk dan pelayanan. Sedangkan menurut Ma'ruf definisi harga adalah unsur yang didalamnya terdapat berbagai unsur bauran pemasaran yang mudah disesuaikan dan mampu menghasilkan laba bagi paritel. Jadi, harga mempunyai peranan terhadap pendapatan dan laba bersih dari perusahaan. Harga mengkomunikasikan posisi nilai yang ada diperusahaan kepada pasarpasar tentang produk dan mereknya. Hal ini merupakan cara penjual untuk membedakan 
penawaran produk dari para pesaing, sehingga dalam menetapkan harga bisa dipertimbangkan sebagai fungsi diferensi barang dalam pemasaran. Sedangkan menurut Husain Umar Harga adalah nilai yang ditukarkan oleh konsumen dengan maksud agar memperoleh manfaat atas kepemilikan dan penggunaan produk atau jasa yang nilainya sudah ditetapkan oleh penjual dan pembeli dengan cara tawar menawar. Atau bisa jadi harga tersebut sudah ditetapkan oleh penjual dan dijual dengan harga yang sama kepada setiap pembeli. Harga juga merupakan faktor penentu yang dapat mempengaruhi tingkat pembelian, karena hal ini masih terjadi di negara-negara dunia ketiga, dikalangan masyarakat sosial yang kurang mampu, serta pada kebutuhan pokok sehari-hari. namun sekarang terdapat beberapa faktor lain selain harga yang menjadi relatif lebih penting ketika akan melakukan pembelian. Jadi, kesimpulannya adalah Harga merupakan kesepakatan nilai tukar yang merupakan syarat dalam transaksi pembelian. Harga bisa diartikan dengan sesuatu yang dikeluarkan oleh pembeli berupa uang atau barang yang bernilai dengan maksud untuk menerima produk atau barang (Harjanto 2009:26). Harga juga merupakan unsur bauran pemasaran yang dapat memberikan pendapatan bagi pelaku organisasi, secara sederhana harga merupakan jumlah (satuan moneter) atau aspek lain (non moneter) yang didalamnya mengandung utilitas tertentu untuk mendapatkan suatu produk.

\section{Kualitas Produk}

Kualitas produk merupakan kondisi atau sifat dan karakteristik suatu produk atau jasa berdasarkan kemampuan yang diharapkan dengan tujuan untuk memuaskan kebutuhan bagi konsumen (Kotler dan Keller, 2012:143). Belakangan ini terjadi persaingan merek produk yang tajam. Hal ini memaksa para penjual untuk memberikan daya tarik kekhasan dan keunikan yang dimiliki produk yang akan dijual, dengan cara yang lebih baik dari pada produk yang dijual oleh pesaing. Konsumen lebih memilih suatu merek dengan kualitas produk yang baik. Kualitas produk dapat mempengaruhi pembelian dan merupakan elemen utama yang dapat mempengaruhi perilaku pembelian konsumen. Sedangkan menurut Kotler Amstrong (2004: 354) kualitas produk merupakan kemampuan produk dalam menghasilkan manfaat, fungsi dan kinerjanya dengan memenuhi keinginan dan kebutuhan konsumen. Kualitas produk merupakan hal penting dan harus dimiliki oleh sebuah produk, sehingga produsen dituntut agar mampu menghasilkan produk yang unggul dan berkualitas supaya bisa menarik minat pembeli dan bisa memenangkan persaingan pasar.

\section{Keputusan Pembelian}

Merupakan salah satu komponen perilaku konsumen dalam melakukan pembelian. Konsumen akan melalui tahap demi tahap untuk memutuskan produk apa yang ingin dibeli. Keputusan pembelian adalah kegitan manusia yang menggunakan pendekatan dalam menyelarasikan masalah untuk membeli suatu barang atau jasa guna memenuhi kebutuhan 
dan keinginannya. Yang terdiri dari pengenalan produk, pencarian informasi, keputusan pembelian terhadap produk dan tingkah laku (perilaku konsumen) setelah pembelian.

Perilaku konsumen menurut Basu Swastha ialah suatu kegiatan individu yang terlibat secara langsung dalam mendapatkan, menggunakan serta memanfaatkan barang dan jasa. Dalam proses pengambilan keputusan pembelian, persiapan dan penerapan kegiatan perilaku konsumen juga akan menentukan. Proses tersebut tidak selalu dilakukan oleh konsumen dalam melakukan transaksi pembelian terhadap produk. Karena pada umumnya pengambilan keputusan akan lebih mudah pada saat pembelian yang kedua kalinya (pembelian ulang) atau pembelian yang sifatnya berlangsung secara terus menerus terhadap produk yang sama. Dalam indikator pengukuran keputusan pembelian Hsu dan Chang mengemukakan pendapatnya sebagai berikut ; untuk pemenuhan kebutuhan dan keinginan akan suatu produk keinginan akan mencoba produk tersebut, terjadinya kemantapan akan kualitas produk yang ingin dibeli, keputusan pembelian ulang terhadap produk tersebut. Sedangkan menurut Sweeney indikator keputusan pembelian adalah buy or not buy yaitu berhubungan langsung dengan keyakinan dalam pembelian dan would not expect any problem yaitu harapan agar tidak mendapatkan suatu resiko dan masalah, serta mempertimbangkan manfaat (benefit) dari suatu produk yang dibeli.

\section{Strategi Harga}

Proses menetapkan harga merupakan faktor kunci untuk mengamankan keuntungan (profit). Harga merupakan komponen bauran pemasaran yang dapat menentukan pendapatan perusahaan, sedangkan untuk komponen yang lain seperti produk, distribusi dan promosi akan mengeluarkan biaya. Ketika harga yang ditetapkan tepat maka akan menghasilkan suatu permintaan dan keuntungan yang optimal. Didalam kerangka strategi penetapan harga yang paling penting adalah untuk mencapai suatu tujuan dalam perusahaan. Harga akan mempengaruhi permintaan, penawaran, keuntungan dan posisi produk dipasar. Dalam penetapan harga sangat berimplikasi terhadap pengeluaran biaya. Misalnya suatu perusahaan akan mengeluarkan produk dengan kualitas bagus dan perusahaan tersebut akan melakukan promosi untuk mengenalkan produk tersebut kepada konsumen dan meyakinkan bahwa produk tersebut memang memiliki kualitas bagus dan unggul, sehingga perusahaan akan mengeluarkan biaya untuk mempromosikan produk tersebut.

Dalam strategi perdagangan terdapat beberapa hal yang perlu diperhatikan dalam menawarkan harga produk untuk mengambil keuntungan. Meningkatkan kualitas pemasaran sebaiknya menggunakan strategi seperti melakukan keterbukaan antara harga dan keuntungan yang diperoleh. Mengambil keuntungan yang wajar dalam arti harga yang ditawarkan tersebut tidak terlalu mahal sehingga cukup memberi keuntungan bagi pedagang dan tidak merugikan pembeli. Atau juga bisa dilakukan dengan cara menjual produk dengan memberikan diskon atau potongan harga kepada konsumen. Strategi tersebut dilakukan untuk meningkatkan penjualan dan mempertahankan loyalitas pembeli. 


\section{Peranan Harga}

Harga berperan penting dalam perekonomian secara makro, konsumen dan perusahaan. (Tjiptono dan Chandra, $2012: 319$ )

a) Dalam perekonomian, harga produk dipengaruhi oleh sewa, tingkat upah, bunga, laba dan faktor produksi seperti tenaga kerja, modal dan kewirausahaan untuk menentukan daya tarik pembeli dalam proses penawaran dan permintaan.

b) Bagi konsumen, selain faktor harga yang dijadikan pertimbangan pembelian produk. Ternyata mayoritas konsumen sering memperhatikan faktor lain yang berkaitan dengan produk seperti citra merek (Brand image), lokasi toko, pelayanan, fitur produk dan kualitas produk. Kualitas produk yang tinggi akan mencerminkan harga yang tinggi, begitupun sebaliknya jika kualitas produk tersebut kurang bagus maka harganya pun murah.

c) Bagi perusahaan harga merupakan bauran pemasaran yang menghasilkan pendapatan, tetapi bauran pemasaran tersebut juga membutuhkan pengeluaran dana seperti produk, distribusi dan promosi. Permintaan terhadap produk dipengaruhi oleh harga yang menjadi determinan utama, selain itu harga juga merupakan determinan dari pengaruh persaingan yang berada di pangsa pasar perusahaan.

Tabel 1. Observasi Harga Produk pada Tahun 2020

\begin{tabular}{|l|l|l|c|c|}
\hline No & Kelompok & \multicolumn{1}{|c|}{ Jenis Barang } & $\begin{array}{c}\text { Harga } \\
\text { Satuan (Rp) }\end{array}$ & Harga Grosir (Rp) \\
\hline \multirow{2}{*}{1.} & Sayuran & Jagung & 5.000 & $80.000 / 40 \mathrm{~kg}$ \\
& & Kubis & 9.000 & $70.000 / 14 \mathrm{~kg}$ \\
& & Kentang & 12.000 & $100.000 / 12 \mathrm{~kg}$ \\
& & Tomat & 10.000 & $40.000 / 8 \mathrm{~kg}$ \\
& & Wortel & 10.000 & $40.000 / 8 \mathrm{~kg}$ \\
\hline \multirow{2}{*}{2.} & Bahan Pokok & Beras & 11.500 & $300.000 / 10 \mathrm{liter}$ \\
& & Minyak Goreng & 13.000 & $150.000 / 12$ liter \\
& & Gula Pasir & 17.500 & $500.000 / 35 \mathrm{~kg}$ \\
& & Bawang Putih & 25.000 & $600.000 / 25 \mathrm{~kg}$ \\
& & Bawang Merah & 38.000 & $500.000 / 15 \mathrm{~kg}$ \\
\hline 3. & Alat-alat Rumah & Sapu & 12.000 & $200.000 / 20 \mathrm{pcs}$ \\
& Tangga & Gayung & 8.000 & $150.000 / 25 \mathrm{pcs}$ \\
& & Panci & 20.000 & $500.000 / 28 \mathrm{pcs}$ \\
& & Wajan & 25.000 & $400.000 / 20 \mathrm{pcs}$ \\
& & Ember & 35.000 & $800.000 / 25 \mathrm{pcs}$ \\
\hline
\end{tabular}

Berdasarkan Tabel 1 diatas, produk adalah suatu barang yang ditawarkan dan diperjualbelikan untuk dikonsumsi, dimiliki, dan dipakai sehingga dapat memuaskan suatu 
keinginan dan kebutuhan. Secara konseptual produk ialah sesuatu yang bisa ditawarkan sebagai usaha untuk mencapai tujuan dari sebuah organisasi dengan cara memenuhi kebutuhan dan keinginan konsumen yang sesuai dengan kapasitas organisasi dan kompetensi serta daya beli dipasar. Seorang produsen dalam mengolah produk sebaiknya memperhatikan keunggulan produksinya diantara produk yang lain, seperti mulai menatanya dari segi kualitas, desain, bentuk, rasa, maupun pelayanan yang mana tujuan utamanya selain untuk mendapatkan keuntungan juga tetap memperhatikan nilai kepuasan konsumen.

Pada penelitian kali ini dilakukan di Dsn. Krajan, Ds. Sukorejo, Kec Sukorejo, Kab. Ponorogo, Provinsi Jawa Timur. Dengan melakukan penelitian terhadap harga berbagai jenis produk yaitu sayuran, barang pokok, dan berbagai alat rumah tangga. Pada setiap produk memiliki kelompok barang masing- masing, seperti yang sudah ditulisakan dalam hasil penelitian. Banyaknya jenis produk yang disediakan oleh produsen merupakan salah satu bentuk pemenuhan kebutuhan konsumen, karena kebutuhan manusia terdapat berbagai macam. Yang pertama, Barang pokok merupakan produk yang sangat dibutuhkan oleh manusia untuk kelangsungan hidupnya, seperti Beras, Minyak Goreng, Gula Pasir, bawang putih, bawang merah dan lain-lain. Yang kedua, sayuran. Berbagai jenis sayuran, seperti jagung, kubis, kentang dan lain-lain yang nantinya akan mempengaruhi harga terhadap barang tersebut. Yang ketiga, alat rumah tangga, produk ini lebih kepada barang pelengkap yaitu barang untuk memenuhi keinginan manusia.

Tabel 2. Harga Produk dan Perubahan Pada Kurun Waktu

Tabel 2.1 Harga Produk Pada Bulan Maret Tahun 2020

\begin{tabular}{|l|l|l|c|c|}
\hline No. & \multicolumn{1}{|c|}{ Kelompok } & Jenis Barang & $\begin{array}{c}\text { Harga Satuan } \\
\text { (Rp) }\end{array}$ & Harga Grosir (Rp) \\
\hline 1. & Sayuran & Jagung & 6.000 & $200.000 / 40 \mathrm{~kg}$ \\
& & Kubis & 8.000 & $300.000 / 50 \mathrm{~kg}$ \\
& & Kentang & 10.000 & $250.000 / 30 \mathrm{~kg}$ \\
& & Tomat & 12.000 & $200.000 / 40 \mathrm{~kg}$ \\
& & Wortel & 11.000 & $400.000 / 40 \mathrm{~kg}$ \\
\hline 2. & Bahan Pokok & Beras & 11.000 & $700.000 / 70 \mathrm{liter}$ \\
& & Minyak Goreng & 13.000 & $110.000 / 12 \mathrm{liter}$ \\
& & Gula Pasir & 26.000 & $500.000 / 40 \mathrm{~kg}$ \\
& & BawangPutih & 37.000 & $500.000 / 20 \mathrm{~kg}$ \\
& & Bawang Merah & 12.000 & $500.000 / 15 \mathrm{~kg}$ \\
\hline 3. & Alat-alat Rumah & Sapu & 8.000 & $200.000 / 20 \mathrm{pcs}$ \\
& Tangga & Gayung & 18.000 & $150.000 / 25 \mathrm{pcs}$ \\
& & Panci & 24.000 & $200.000 / 12 \mathrm{pcs}$ \\
& & Wajan & 32.000 & $500.000 / 20 \mathrm{pcs}$ \\
& & Ember & $500.000 / 16 \mathrm{pcs}$ \\
\hline
\end{tabular}

Tabel 2.2 Harga Produk Pada Bulan April Tahun 2020 


\begin{tabular}{|r|l|l|c|c|}
\hline No. & \multicolumn{1}{|c|}{ Kelompok } & \multicolumn{1}{|c|}{ Jenis Barang } & Harga Satuan (Rp) & Harga Grosir (Rp) \\
\hline 1. & Sayuran & Jagung & 5.000 & $800.000 / 40 \mathrm{~kg}$ \\
& & Kubis & 7.000 & $350.000 / 70 \mathrm{~kg}$ \\
& & Kentang & 11.000 & $300.000 / 30 \mathrm{~kg}$ \\
& & Tomat & 10.000 & $200.000 / 25 \mathrm{~kg}$ \\
& & Wortel & 12.000 & $400.000 / 40 \mathrm{~kg}$ \\
\hline 2. & Bahan Pokok & Beras & 11.000 & $700.000 / 70 \mathrm{liter}$ \\
& & Minyak Goreng & 11.000 & $110.000 / 12 \mathrm{liter}$ \\
& & Gula Pasir & 12.000 & $350.000 / 32 \mathrm{~kg}$ \\
& & Bawang Putih & 30.000 & $600.000 / 25 \mathrm{~kg}$ \\
& & Bawang Merah & 35.000 & $700.000 / 25 \mathrm{~kg}$ \\
\hline 2. & Alat-alat Rumah & Sapu & 12.000 & $200.000 / 20 \mathrm{pcs}$ \\
& Tangga & Gayung & 8.000 & $150.000 / 25 \mathrm{pcs}$ \\
& & Panci & 20.000 & $500.000 / 28 \mathrm{pcs}$ \\
& & Wajan & 25.000 & $400.000 / 20 \mathrm{pcs}$ \\
& & Ember & 30.000 & $500.000 / 30 \mathrm{pcs}$ \\
\hline
\end{tabular}

Tabel 2.3 Harga Produk Pada Bulan Mei Tahun 2020

\begin{tabular}{|c|l|l|c|c|}
\hline No & \multicolumn{1}{|c|}{ Kelompok } & Jenis Barang & $\begin{array}{c}\text { Harga Satuan } \\
\text { (Rp) }\end{array}$ & Harga Grosir (Rp) \\
\hline 1. & Sayuran & Jagung & 5.000 & $800.000 / 40 \mathrm{~kg}$ \\
& & Kubis & 10.000 & $300.000 / 50 \mathrm{~kg}$ \\
& & Kentang & 8.000 & $400.000 / 50 \mathrm{~kg}$ \\
& & Tomat & 8.000 & $200.000 / 40 \mathrm{~kg}$ \\
\hline 2. & Bahan Pokok & Wortel & 12.000 & $200.000 / 40 \mathrm{~kg}$ \\
\hline & & Beras & 12.000 & $600.000 / 60 \mathrm{liter}$ \\
& & Minyak Goreng & 15.000 & $120.000 / 12 \mathrm{liter}$ \\
& & Gula Pasir & 35.000 & $700.000 / 50 \mathrm{~kg}$ \\
& & BawangPutih & 40.000 & $800.000 / 25 \mathrm{~kg}$ \\
& & Bawang Merah & 12.000 & $1.000 .000 / 35 \mathrm{~kg}$ \\
\hline & Alat-alat Rumah & Sapu & 9.000 & $200.000 / 20 \mathrm{pcs}$ \\
& Tangga & Gayung & 20.000 & $250.000 / 32 \mathrm{pcs}$ \\
& & Panci & 25.000 & $500.000 / 28 \mathrm{pcs}$ \\
& & Wajan & 35.000 & $400.000 / 20 \mathrm{pcs}$ \\
\hline
\end{tabular}

Pada Tabel 2 tersebut terjadi perubahan harga produk dalam pasar, perubahan harga barang dipasar dipengaruhi oleh jumlah permintaan dan penawaran atas barang. Harga pasar terjadi karena adanya kesepakatan antara penjual dan pembeli, selain itu penentuan harga 
barang di pasar tergantung dari jumlah permintaan dan penawaran. Oleh karena itu perlu melakukan analisis terhadap permintaan dan penawaran untuk mementukan harga dari barang tersebut. Analisis permintaan dan penawaran pada barang digunakan untuk mengetahui mekanisme yang terjadi di pasar. Jadi, tanpa adanya campur tangan dari pemerintah permintaan dan penawaran akan mencapai keseimbangan harga. Perubahan harga dan jumlah barang bervariasi sepanjang waktu hal ini dikarenakan jumlah permintaan dan penawaran bereaksi terhadap variabel-variabel ekonomi.

Pada penelitian di Dsn. Krajan, Ds. Sukorejo, Kec. Sukorejo, Kab. Ponorogo, Provinsi Jawa Timur Mengenai sejumlah pedagang atau produsen yang menjual barang dagangannya untuk memenuhi kebutuhan konsumen. Tentunya jenis produk yang dijual memiliki harga jual yang berbeda-beda mulai dari harga rendah, sedang maupun harga tinggi. Para produsen dalam menentukan harga tersebut sesuai dengan tingkat kebutuhan, faktor produksi dan tingkat permintaan terhadap produk tersebut. Pada sayuran harga tertinggi adalah kentang yaitu Rp 12.000/kg, pada barang pokok harga tertinggi adalah bawang merah yaitu Rp $38.000 / \mathrm{kg}$, dan pada alat rumah tangga harga tertinggi pada ember yaitu Rp 35.000. Adanya penentuan harga yang berubah-ubah terjadi karena disebabkan oleh produsen yang ingin meningkatkan harga jual dan bertujuan ingin memaksimalkan laba yang diperoleh dan juga tingkat kebutuhan apabila produk tersebut merupakan suatu barang pokok maka seberapa pun harganya konsumen akan tetap membeli dan juga akan mempengaruhi permintaan terhadap barang tersebut.

Tabel 3. Data Demografi (Pengelompokan Konsumen)

\begin{tabular}{|c|c|c|c|}
\hline No. & Kelompok & Jenis Pengelompokan & Keterangan (Rata-rata) \\
\hline 1. & Sayuran & $\begin{array}{l}\text { Nama Responden } \\
\text { Jenis Kelamin (Gender) } \\
\text { Alamat } \\
\\
\text { Pendapatan } \\
\text { Pendidikan } \\
\text { Pekerjaan } \\
\text { Usia } \\
\text { Agama }\end{array}$ & $\begin{array}{l}\text { Mesringah } \\
\text { Perempuan } \\
\text { Dsn. Krajan, Ds. Sukorejo, Kec. } \\
\text { Sukorejo, Kab. Ponorogo, Provinsi } \\
\text { Jawa Timur. } \\
\text { >Rp. } 2.500 .000 \\
\text { Tamat SD/Sederajat } \\
\text { Pedagang Toko } \\
\text { 45 Tahun } \\
\text { Islam }\end{array}$ \\
\hline 2. & $\begin{array}{l}\text { Bahan } \\
\text { Pokok }\end{array}$ & $\begin{array}{l}\text { Nama Responden } \\
\text { Jenis Kelamin (Gender) } \\
\text { Alamat } \\
\\
\text { Pendapatan } \\
\text { Pendidikan } \\
\text { Pekerjaan }\end{array}$ & $\begin{array}{l}\text { Mufadillah } \\
\text { Perempuan } \\
\text { Dsn. Krajan, Ds. Sukorejo, Kec. } \\
\text { Sukorejo, Kab. Ponorogo, Provinsi } \\
\text { Jawa Timur. } \\
\text { >Rp. } 1.000 .000 \\
\text { Tamat SD/Sederajat } \\
\text { Wiraswasta }\end{array}$ \\
\hline
\end{tabular}




\begin{tabular}{|c|c|c|c|}
\hline & & $\begin{array}{l}\text { Usia } \\
\text { Agama }\end{array}$ & $\begin{array}{l}48 \text { Tahun } \\
\text { Islam }\end{array}$ \\
\hline 3. & $\begin{array}{l}\text { Alat-alat } \\
\text { Rumah } \\
\text { Tangga }\end{array}$ & $\begin{array}{l}\text { Nama Responden } \\
\text { Jenis Kelamin (Gender) } \\
\text { Daerah } \\
\\
\text { Pendapatan } \\
\text { Pendidikan } \\
\text { Pekerjaan } \\
\text { Usia } \\
\text { Agama }\end{array}$ & $\begin{array}{l}\text { Kateno } \\
\text { Laki-laki } \\
\text { Dsn. Krajan, Ds. Sukorejo, Kec. } \\
\text { Sukorejo, Kab. Ponorogo, Provinsi } \\
\text { Jawa Timur. } \\
\text { >Rp. } 1.500 .000 \\
\text { SLTP/Sederajat } \\
\text { Kuli Bangunan } \\
50 \text { Tahun } \\
\text { Islam }\end{array}$ \\
\hline
\end{tabular}

Pada Tabel 3 tersebut adalah pengelompokan konsumen atau Demografi Pasar. Yang terjadi di Ds. Sukorejo Kec. Sukorejo Kab. Ponorogo, Provinsi Jawa Timur. Menurut hasil penelitian Sayuran banyak diminati oleh para pembeli yang mayoritas perempuan karena sayuran digunakan dan diperlukan dalam kehidupan sehari-hari untuk bahan dasar memasak. Bahan Pokok, menurut hasil penelitian bahan pokok banyak diminati oleh para pembeli yang mayoritas perempuan karena bahan pokok digunakan dan diperlukan dalam kehidupan sehari-hari. dan untuk peralatan Rumah Tangga kaum laki-laki lebih mendominasi dari pada kaum perempuan.

Dari penelitian diatas terdapat beberapa faktor penyebab terjadinya kenaikan dan penurunan harga pokok. Harga menjadi sesuatu yang sangat penting dalam pemasaran terhadap suatu produk demi berlangsungnya kegiatan jual beli. Tingkat harga pun tidak selalu tetap, artinya produk bisa mengalami perubahan harga sewaktu-waktu, tergantung pada kondisi dan cuaca pada waktu tertentu. Baik mengalami penurunan maupun kenaikan terhadap harga pokok. Faktor yang dapat menyebabkan Penurunan maupun kenaikan harga pokok pada berbagai jenis produk, yaitu: tingkat permintaan dan penawaran, cuaca, faktor produksi, pertumbuhan penduduk, tingkat pendapatan.

Tingkat permintaan dan penawaran dikatakan seimbang jika jumlah barang yang diminta sama dengan barang yang tersedia untuk dijual (Balance). Ketidak seimbangan antara ketersediaan dan permintaan dapat menyebabkan kenaikan dan penurunan harga pokok. Selain itu kecenderungan akan meningkatnya konsumsi masyarakat diakibatkan oleh banyaknya melakukan pembelian kebutuhan pokok sedangkan ketersediaan akan barang yang semakin menipis dan terbatas, sehingga membuat harga tersebut meningkat. Sebaliknya ketika ketersediaan barang lebih banyak dari pada barang yang diminta, maka harga barang tersebut mengalami penurunan. Faktor cuaca juga menjadi penyebab kenaikan dan penurunan harga pokok. Hal itu sangat berdampak besar terhadap kebutuhan sayuran. Ketika kemarau 
panjang, kebutuhan akan sayuran cenderung mengalami kenaikan harga seperti: cabe, jagung, kubis, kentang, tomat, wortel, buncis, sawi putih, dan mentimun. hal ini disebabkan karena keterbatasan stok sayur akibat musim kemarau, para petani mengalami kesulitan air atau bahkan mengalami gagal panen karena sayuran yang ditanam mengering. Dan sebaliknya pada saat musim penghujan sayuran cenderung akan mengalami penurunan harga karena ketersediaan barang yang melimpah melebihi jumlah permintaan.

Faktor produksi yang menyebabkan kenaikan dan penurunan harga pada peralatan rumah tangga terjadi karena harga bahan baku yang mahal dan teknologi yang digunakan semakin canggih sehingga harga akan cenderung mahal, namun ketika harga bahan baku murah, maka harga peralatan rumah tangga akan mengalami penurunan. Selain itu kualitas dan kuantitas juga bisa menyebabkan naik turunnya harga, ketika kualitas dan kuantitas barangnya bagus maka harganya pun akan semakin mahal (Ada harga ada kualitas) slogan yang dimunculakan oleh para penjual, dan sebaliknya jika kualitas dan kuantitas barang tersebut tidak terlalu bagus, maka bisa dibeli dengan harga yang murah. Pertumbuhan dan tingkat pendapatan masyarakat dapat menyebabkan harga pokok mengalami kenaikan maupun penurunan. Pertumbuhan penduduk yang meningkat serta pendapatan masyarakat yang tinggi akan meyebabkan permintaan terhadap suatu barang mengalami peningkatan, sehingga harga akan mengalami kenaikan, dan begitupun sebaliknya.

\section{PENUTUP}

\section{Kesimpulan}

Dalam memenuhi kebutuhan sehari-hari masyarakat lebih mementingkan kebutuhan yang wajib dibeli misalnya seperti makanan, minuman, kebutuhan pokok, kebutuhan pelengkap dan kebutuhan lainnya. Maka konsumen tersebut akan memperhatikan tingakatan harga barang karena harga digunakan sebagai penentu seseorang pembeli dalam menentukan keputusan transaksi pembelian atas barang maupun jasa. Selain itu, konsumen juga akan memperhatikan produk yang akan dibeli. Banyaknya jenis produk yang disediakan oleh produsen merupakan bentuk pemenuhan kebutuhan manusia karena kebutuhan manusia sangat bermacam-macam.

Faktor Penyebab kenaikan dan penurunan Harga Produk disebabkan oleh kualitas dan kuantitas dan kualitas produk, tingkat permintaan dan penawaran konsumen, serta cuaca lingkungan. Harga menjadi sesuatu yang sangat penting dalam pemasaran terhadap suatu produk demi berlangsungnya kegiatan jual beli. Tingkat harga tidak selalu tetap, artinya produk bisa mengalami perubahan harga sewaktu- waktu, dan tergantung pada setiap kondisi tertentu. Baik itu mengalami penurunan maupun kenaikan terhadap harga pokok.

\section{Saran}

Dari hasil penelitian dan pembahasan terdapat saran yang diperlukan dalam pembentukan (penetapan) harga oleh pedagang terhadap kebutuhan pokok. sebaiknya ada 
pengawasan dari pemerintah, karena dilihat dari pola saluran distribusi komoditas dari masing-masing daerah berbeda. Pemerintah juga harus mengetahui keadaan pasokan barang kebutuhan pokok terutama ketika barang tersebut semakin menipis atau sedikit, karena ditakutkan terjadi kecurangan dalam pendistribusian barang. Maka dari itu pemerintah diharapkan untuk menjamin kemakmuran dan kesejahteraan masyarakat dengan menjamin terpenuhinya kebutuhan pokok bagi masyarakat. Bagi pembeli, memiliki sifat komsutif yang berlebihan jika terus menerus dilakukan akan berdampak buruk bagi perekonomian. Maka dari itu untuk memenuhi kebutuhan yang sesuai tidak perlu membeli barang terlalu banyak yang sebenarnya tidak dibutuhkan atau secukupnya dan seperlunya saja. Lebih baik membeli barang yang benar-benar bermanfaat dan dibutuhkan. Bagi peneliti selanjutnya, akan lebih baik jika memperluas cakupan penelitian mengenai tingkatan harga dan mengembangkan penelitian dengan meneliti variabel-variabel tentang faktor lain yang dapat mempengaruhi perubahan harga pada produk.

\section{DAFTAR PUSTAKA}

Abadi, Lilian Yulia. (2016). Evaluasi Strategi Penetapan Harga Jual Dalam Bisnis Gourmet Land Cafe. JURNAL PERFORMA: Jurnal Manajemen dan Start-Up Bisnis, Vol.1 No.1.

Anggraeni, Dita Putri, Srikandi Kumadji, Sunarti. (2016). Pengaruh Kualitas Produk Terhadap Kepuasan Dan Loyalitas Pelanggan (Survei pada Pelanggan Nasi Rawon di Rumah Makan Sakinah Kota Pasuruan). Jurnal Administrasi Bisnis (JAB), Vol.37 No.1.

Martini, Tina. (2015). Analisis Pengaruh Harga, Kualitas Produk Dan Desain Terhadap Keputusan Pembelian Kendaraan Bermotor Merek Honda Jenis Skutermatic. Jurnal Penelitian IAIN Kudus, Vol.9 No.1.

Marzuki, Ismail, Fatih Ramdaniah. (2019). Strategi Pemasaran Pedagang Sembako Dalam Meningkatkan Taraf Ekonomi Perspektif Ekonomi Islam. JURNAL IQTISHADIA: Jurnal Ekonomi \& Perbankan Syariah, Vol.6 No.1 .

Rizal, Achmad. (2020). Buku Ajar Manajemen Pemasaran Di Era Masyarakat Industri 4.0. Yogyakarta: Deepublish.

Satria, Arief Adi. (2017). Pengaruh Harga, Promosi, dan Kualitas Produk Terhadap Minat Beli Konsumen Pada Perusahaan A-36. JURNAL PERFORMA: Jurnal Manajemen dan Start-Up Bisnis, Vol.2 No.1

Sugiarto dkk. (2020). Ekonomi Mikro. Jakarta: PT Gramedia Pustaka Utama.

Soei, Christanti N, H. Sabijono, T. Runtu. (2014). Penentuan Harga Jual Produk Dengan Menggunakan Metode Cost Plus Pricing pada UD. Sinar Sakti. Jurnal EMBA, Vol.2 No.3.

Patra, I Ketut, Agus Salim. (2014). ANALISIS PENETAPAN HARGA JUAL DALAM MENINGKATKAN LABA PADA RUMAH MAKAN ULU BETE LAUT DI MASAMBA KABUPATEN LUWU UTARA. Jurnal Ekonomi Pembangunan STIE Muhammadiyah Palopo, Vol.01 No.02. 
El Mudhorib: Jurnal Kajian Ekonomi Perbankan Syariah

Vol. 1 No. 2 Desember 2020

E-ISSN : 2722-5615

Winarso, Widi, M. Fadhli Nursal, Ery Teguh Prasetyo. (2018). Analisis Strategi Penetapan Harga Produk Usaha Kecil Dan Menengah Terhadap Volume Penjualan (Studi Kasus: Pada Pedagang Bakso di Bekasi Utara). Jurnal for Business and Entrepreneurship, Vol.2 No.1. 